\title{
THE BIRDS OF
}

SPRINGRIRLD AND VICINITY $33^{3}=$

ROBIERT O. MORRIS 


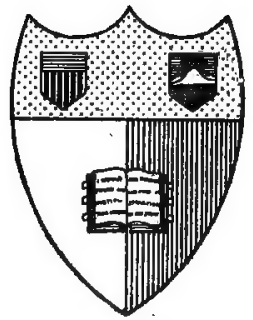

\section{Carnell Antuergity Mibrary}

Ithara, Nem

BOUGHT WITH THE INCOME OF THE

\section{FISKE ENDOWMENT FUND}

THE REQUEST OF

\section{WILLARD FISKE}

LIBRARIAN OF THE UNIVERSITY 1BB日-18ES

1905

\section{RETURN TO}

\section{ALBERT R. MANN LIBRARY}

ITHACA, N. Y. 


\section{OL 684.M4Mell University Library}

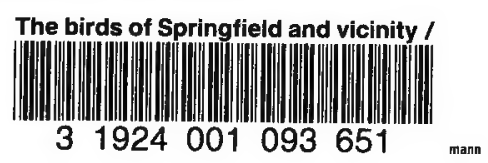




\section{Cornell University Library}

The original of this book is in the Cornell University Library.

There are no known copyright restrictions in the United States on the use of the text.

http://www.archive.org/details/cu31924001093651 



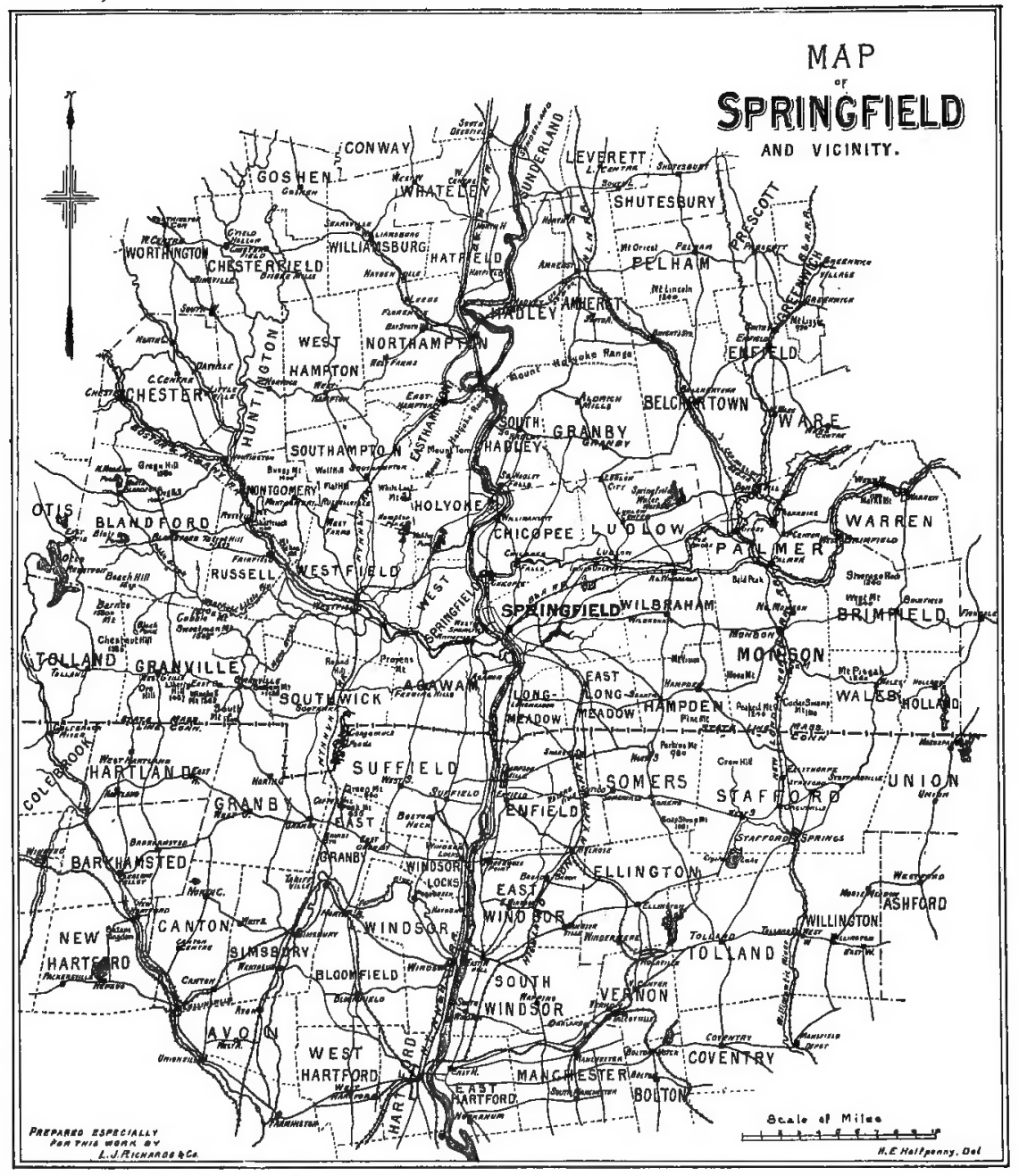




\section{THE}

\section{BIRDS OF SPRINGFIELD AND VICINITY}

BY

ROBERT O. MORRIS

SPRINGFIELD, MASS.

PUBLISHED BY HENRY R. JOHNSON 



\section{The Birds of Springfield and Vicinity.}

The Hydrographic valley of the Connecticut at Springfield is about sixty miles wide, and the river here is somewhat east of the center of the basin. The State of Connecticut lies three and a half miles south of Springfield, the town of Longmeadow intervening. Thirteen miles to the west, a mountain range rises abruptly from the level land at Westfield, continuing bey'ond to the Housatonic Valley, forming a portion of the socalled Berkshire hills, and running north until it joins the Green mountains in Vermont. The highest point of this range in Hampden County is "Round Top" in Chester, which reaches an altitude of $\mathrm{I} 800$ feet. About ten miles to the east of Springfield lies a range of considerably less height, which is locally called the "Wilbraham Hills," and extends north to New Hampshire, where it merges into the White mountain range. Five miles to the west of Springfield is a series of Hills, 400 to 900 feet in height, of trap rock formation, which continues up the valley and crosses the river, south of the greater part of Northampton. Here the hills are higher, Mount Tom and Nonotuck on the west side, and Holyoke on the east, reaching an altitude of about $\mathrm{I} 200$ feet.

The Connecticut River at Springfield is but forty feet above tide water, and except in time of freshet, is a sluggish stream, averaging about $\mathrm{I} 200$ feet in width. The important branches in this vicinity are the Chicopee, Mill and Scantic Rivers, that enter from the east, and Westfield and Farmington Rivers, that come from the west, and the largest natural landlocked body of water is Lake Congamond in Southwick, which covers about 4ro acres. In nearly all the towns there are small ponds, both natural and artificial.

The land of the river towns is sparsely timbered, being mostly under cultivation. The mountain regions east and west of the river are heavily timbered, chiefly with deciduous trees, consisting principally of chestnut, white oak, gray birch, sugar maple, with a sprinkling of white pines and hem- 
locks, and on the east side the pitch pines are quite numerous. Along the streams nuy be seen the willows, elms, red and white maples, river poplars, alders, pin oaks, and buttonwoods. In Russell and Montgomery there is quite a growth of tulip trees; on the trap rock range the red cedars are common, and here and there in the valley can be found black and red oak, sassafras, black and paper birch, and many other kinds not generally common; on the hills to the west of Westfield there is an immense growth of mountain laurel, and considerable is found on the Wilbraham hills, and a little in the river towns.

One of the great attractions to bird life near Springfield in late Summer and Autumn, particularly to the water birds, lies in the wild rice, Zizania aquatica, that grows so profusely along the banks of the Connecticut river. About twenty years ago many bushels of the seed of this plant was brought from Wisconsin and Canada and scattered along the shores of the Connecticut, and in some of the ponds ; in all the latter the attempt to introduce proved a failure; whether the large quantity that now grows along the banks and in the river is due to the seed that was so distributed, it is pretty hard to say. Prior to 1878 there was quite a little growing here, as had always been the case down the river towards the Sound; about that time the dam across the Connecticut at Enfield, ten miles below Springfield, was raised, which decidedly slackened the current above, making the conditions much more favorable for wild rice to thrive; very likely the rapidly increasing growth here, that began just about that time, was owing to that fact rather than to the planting of the seed; anyway, it then seemed to appear on the river in every suitable place, whether seeded by man or in other ways. Wild celery, vallisneria spiralis, the root of which is a favorite food of some of the duck family, is common here, both in the river and ponds. In order to attract some of the water birds, roots and seeds of this plant were brought here from the West about eighteen years ago and planted in the river, and it was successfully propagated in both ways; which was an unnecessary step, as there was plenty of it here before. Kotweed, Polygonum Amphibium, arrow head, Sagittaria variabilis, button bush, Cephalanthus Occidentalis, ground 
nut, Apios tuberosa, and several kinds of wild grass, all grow along the river, furnishing food for various kinds of surface feeding ducks.

With all the reliable text books on New England birds, a local list may seem to many uncalled for, but we sometimes find bird life different in short distances. For instance, less than fifty miles to the south and west of Springfield, there is a decided change in Summer residents, in the latter direction undoubtedly accounted for by reason of variation in altitude, but in the former the reason is not so apparent, at least why the difference should be so marked in so short a distance and with practically the same flora, temperature, and altitude.

To well know the bird fauna of any particular section of the country, observations must extend over a series of years, and this is particularly true of the water birds ; many of them are very irregular in their appearance, and their visits here are often short, owing to the absence of their favorite food, and in late years to the persistent manner in which they are driven away. An observer near a river like the Connecticut, and above tide water, by the latter part of Summer, can make some reliable calculations as to the probabilities of the presence of surface feeding ducks in the river, a month or two later. If the rainfall has been heavy during the Summer, and the river high, the vegetation along the shore will be destroyed, or only have a stunted growth; thus their food supply being scarce, if they stop here on their way South, they soon pass on. When the Connecticut river is high and roily during the time of their migration, none of the sea ducks make any lengthy stay, it being so hard for them to find their food; and few, if any, of the so-called" shore birds stop here when such conditions prevail. In this list I have indicated the authority for the occurrence of a bird here, if it is otherwise than from my observation, and have only made a record when the evidence was conclusive. I do not treat towns more than twenty-five miles distant as being within the vicinity of Springfield. The numbers prefixed to the names of the birds correspond with those used in the check list adopted by the American Ornithologist Union, and with very few exceptions are those found in Chapman's Hand-book of the Birds of Eastern North America. 
2. Colymbus holboellii (Reinh.). Holboeld's GreBE. Chiefly an uncommon winter visitor, but Dr. J. A. Allei records its capture in Springfield, the third week in May, in full breeding plumage. The specimen in the Science building, Springfield, was taken alive in Otis a few winters ago and sent to Forest Park, where it soon died. Two have been taken at Belchertown. (See Birds of Amherst, page 45.)

3. Colymbus auritus Linn. Horned Grebe. Some autumns the young of this species are quite common and I have seen them in small flocks; the adults are rarely here. Their food usually consists of frogs, small fish and aquatic insects, but some years ago, while attracting wild ducks by baiting with corn, I found that one of these grebes had developed a decided taste for this grain, and when taken its craw was filled with it. A pair were killed here in full breeding plumage about June I. (See Catalogue of the Birds Found at Springfield.)

\section{Podilymbus podiceps (Linn.). PIED-BILLED} GRFBE. A rare summer resident and a common spring and autumn visitor.

7. Gavia imber (Gunn.). Loon. A not uncommion spring and fall visitor; Dr. J. A. Allen reports it as breeding here occasionally, but that was nearly forty years ago. I have not known of its presence here in summer for a long time.

I . Gavia lumme (Gunn.). RED-THROATED LOON. Rare spring and fall visitor.

31. Uria lomvia (Linn.). Brunnich's Murre. For some unknown cause, during the last five or six years, representatives of this species have paid us a number of visits; previous to that time there appears to be no record of its capture here, and now it is far from being common. I took one November 30, I899, and the same day one was shot in Berkshire county. (See Birds of Berkshire County, page 53.) 
34. Alle alle (Linn.). DovEKIE. Accidental winter visitor, but has been taken here on several occasions, supposed to have been driven from the coast by a storm. In the Catalogue of the Birds of Springfield, Dr. J. A. Allen reports its capture at Greenfield, and in his revised list of birds of Massachusetts, at Springfield. (For report of its occurrence at Belchertown, see Birds of Amherst, page 45.) In the Bulletin of Massachusetts Natural History, published at Amherst for June and July, I 884, it is stated that: "In 1872 a large number of these birds were secured in and about Belchertown pond, not far from here, where they were cast by a severe coast storm."

5I. Larus argentatus Brünn. Herring GULI. Common winter visitant; when the Connecticut is free from ice, a few usually fly slowly up the river during the forenoon, searching for food, and there is a return flight in the afternoon. On several occasions, during open winters, I have found them quite numerous here.

6o. Iarus philadelphia (Ord). Bonaparte's Guli. Rare visitor; July 3I, I 893, three appeared on the river near Springfield, one of which was captured. Dr. J. A. Allen stated that they were occasionally observed here.

70. Sterna hirundo Linn. COMmON TERN. Very rare; one was taken in Longmeadow, September, I878, the only instance that I have known of its presence here.

8o. Rynchops nigra Linn. BLACK SkIMMER. Accidental visitor; after a very severe gale that prevailed the last of August, I893, one was taken in West Springfield.

ro6. Oceanodroma leucorhoa (Viei11.). LEACH'S PETREL. Very rare visitor; in late years, I have known of its capture here but three times; Dr. J. A. Allen stated that it had been taken here in a few instances. In an address delivered at Springfield, on the occasion of the opening of the railroad to Boston, a little over sixty years ago, Gov. Edward Everett, on 
the authority of Rev. W. B. O. Peabody, referred to a recent visit of this "little sea bird" to this region, which he regarded as a good omen. The specimen in the Science building, Springfield, was caught by a cat, in a meadow close by the Connecticut river, in Agawam, September 20, 1900.

\section{I20. Phalacrocorax dilophus (Swain.). DOuble-} CRESTED CORMORANT. During the years I 887 and I888, a number were seen here in small flocks, and several were taken, but with the exception of these two years it has appeared here only as a rare visitor.

I 29. Merganser americanus (Cass.). AMERICAN Merganser. On the Connecticut river and its tributaries this is the most abundant of the duck family, from November I 5 until May I; occasionally it is found on the large ponds, and I have observed it here repeatedly in mid-summer, but have no further evidence of its breeding. One summer, I saw one here in company with a blue-winged teal. During the very cold winters, these mergansers assemble in large numbers on the Connecticut, in the rapid water just below the Enfield dam.

I30. Merganser serrator (Linn.). RED-BREASTED MFRGANSER. Mr. E. O. Damon has taken one specimen in Northampton, and I have done the same near Springfield; with these exceptions, I have never known of its presence here.

I 3I. Lophodytes cucullatus (Linn.). HOODED MERGANSER. A common late autumn migrant; I have not observed it here at other seasons, but it undoubtedly may be found occasionally in early spring.

I32. Anas Boschas Linn. MALIARD. Rather common autumn visitor, arriving about the first of November; I have taken it here in the spring, but it is rare at that season. Usually it may be found associating with Anas obscura, but one year within my experience the mallards appeared in larger numbers than the black ducks, and they then flocked by them- 
selves. They are apparently very fond of corn, and when "baited" on that grain, are loth to proceed on their journey.

133. Anas Obscura Gme1. Black Duck. Abundant in spring and autumn; a few spend the winter with us, and can usually be found in the vicinity of the south branch of Mill river, in Hampden and Wilbraham, from December until March. As the ice closes the ponds and forms along the banks of the Connecticut river, the great body retire, and, even if the winter is open, do not return until spring. A few breed regularly in the ponds in the western part of this section and rarely in the river towns. In July of $\mathrm{r} 898$, a brood nearly grown appeared in Forest Park in Springfield, and associated and fed with the domestic ducks there, and becoming quite tame they were finally captured, alive and taken into winter quarters; a few of them still remain in the park.

\section{I35. Chäulelasmus strepera (Linn.). Gadwall.} Accidental visitor; there are two specimens in the Museum in Springfield, that were taken here many years ago. (See Catalogue of the Birds. Found in Springfield.)

I37. Mareca americana (Gmel.). Baldpate. A not very common, but regular spring and fall visitant; in the autumn of 1884 , they were fairly abundant here.

I39. Nettion carolinensis (Gme1.). GREEN-WINGED TEAL. A not uncommon spring and autumn migrant, but less numerous than the Blue-winged Teal.

I40. Querquedula discors (Linn.). BLUE-WINGED TEAL. A common autumn but a rare spring visitor; in the fall of 1885 , it was abundant. I have seen it here repeatedly in mid-summer, and once I observed a flock in the river about the twentieth of August. One of the specimens in the Museum at Springfield was taken here the last day of May; I have no further evidence of their breeding here, but there is no doubt that at one time they did. 
I42. Spatula clypeata (Linn.). Shoveller. An accidental visitant; the specimen in the Museum in Springfield was captured by William C. Pease, in Longmeadow. It has been taken once or twice near Northampton. (See, Birds in Amherst, page 46.)

143. Dafila acuta (Linn.). PinTaIL. A common autumn visitant but rare in spring. This is the second migrant of the ducks to appear in the autumn, coming about two weeks later than the Blue-winged Teal; I have taken it here as early as the seventeenth of September. For a few weeks in I89I it was abundant on the river.

I44. Aix sponsa (Linn.). WOOD DUck. Common summer resident; until within a few years, one or two pairs bred regularly in Forest Park.

146. Aythya americana (Eyt.). RED-HEAD. Rare autumn visitor and probably here occasionally in the spring. $I$ 'have seen them on the river in large flocks, but that is unusual.

148. Aythya marila (Linn.). American Scaup Duck. Uncommon autumn visitor; I have never known of their being here in any great numbers.

I49. Aythya affinis (Eyt.). Lesser Scaup Duck. Rare spring and common autumn visitor, arriving here about the middle of October. There are plenty of pond snails Limncea Megastoma here, which appear to be their favorite food, and when the Connecticut river is not high and roily they can obtain all they want without much exertion. I have seen five hundred of them on the river at once; they would make us long visits but for the practice of shooters of chasing them with boats, which very soon results in their being driven from this vicinity. The late Dr. Wood of East Windsor Hill has taken them there in the spring, but they are rare at that season.

I 5o. Aythya collaris (Donov.). Ring-NeCked Duck. A rare autumn visitor. 
I 5 . Clangula clangula americana Bonap. AmFrICAN GOLDEN-EYE. Abundant spring and autumn visitor and occasionally here during open winters.

I 53. Charitonetta albeola (Iinn.). BUFFLE-HEAD. Not uncommon in early spring and late autumn. Once in September I found a flock of ten or a dozen on the river, near Springfield, that were evidently young; they permitted a boat to be rowed within easy shooting distance, and after being fired at once, when several were killed, they only flew a short distance and then waited until the boat again approached, when a number more were shot.

I54. Harelda hyemalis (Linn.). OLD SoUAw. Rather rare spring and autumn visitor. I have seen small flocks here.

165. Oidemia deglandi Bonap. WHITE-WINGED ScoTER. Rare; Dr. William Wood captured two at East Windsor Hill. (See Dr. J. A. Allen's Catalogue of the Birds of Springfield.)

I66. Oidemia perspicillata (Linn.). SURF SCOTER. October 23, I 886, I captured one on the river in Longmeadow, which is the only occasion that I have known an individual of this kind to visit us; but my impression is that this species, as well as all the other sea ducks so common on Long Island Sound, are occasionally represented here.

167. Erismatura jamaicensis (Gme1.). RUDDY Duck. During the autumn of 1885 , this duck was common on the waters in the vicinity of Springfield, but with the exception of this season, it has been during the past twenty years a rare spring and fall visitor.

169. (a) Chen hyperborea nivalis (Forst.). GREATER SNów Goose. Rare or accidental visitor; one was wounded and captured near Springfield a number of years ago, and turned loose with a flock of domestic geese in Southwick, with 
which it remained for several years. In the spring of $\mathrm{I} 887$, I saw one in Longmeadow.

I72. Branta canadensis (Linn.). CANADA Goose. Common spring and autumn migrant.

173. Branta bernicla (Linn.). BRANT. One was shot on the Connecticut river above Hartford, in the spring of I876. (See Merriam's Birds of Connecticut, page I21.) Dr Allen, in the Catalogue of the Birds of Springfield, gives it as "not common."

rgo. Botaurus lentiginosus (Montag.). AMERICAN BITTERN. Common summer resident.

I9I. Ardetta exilis (Gme1.). LEAST BITTERn. Rare; Dr. J. A. Allen reports the taking of one by C. W. Bennett; E. O. Damon shot one at Northampton, and I captured one in Longmeadow September I, 1895. As to its presence in Suffield, see Merriam's Birds of Connecticut, page I I3.

I94. Ardea herodias Linn. Great BluE HERON. Transient visitor from April until November, except that it is generally absent during the months of June and July; it may breed here occasionally.

196. Ardea egretta Gme1. AMERICAN EGRET. Rare visitor from the South; one was seen in Forest Park, Springfield, on several occasions during the summer of I897. A specimen was taken in North Hadley, in August, I883, (see Birds of Amherst, page 46,) and it has been reported as having been seen by various reliable observers, within twenty miles of Springfield, but not during the past fifteen years.

197. Ardea candidissima Gme1. SNow Heron. Accidental visitor ; the specimen in the Museum of Natural History, Springfield, was taken by Mr. E. O. Damon at Northampton, and this is the only instance known to me of its presence here. 
20I. Ardea virescens Iinn. Green Heron. Abundant summer resident.

202. Nycticorax nycticorax nævius (Bodd.). Black-Crowned Night Heron. Common summer resident.

208. Rallus elegans Aud. KING Rail. Accidental visitor; a specimen was taken by William C. Pease in Longmeadow, October I9, I895; this is the only record of its occurrence here. (See The Auk, vol. I3, page 86.)

2I I. Rallus crepitans Gmel. Clapper RaIl. Accidental visitor; one was taken in the Hadley Meadows, and Mr. E. O. Damon captured one at Northampton.

212. Rallus virginianus Linn. VIrginia RaIL. A common summer resident; this and the following species are more numerous here in summer than is generally believed. I know of a man who used to tie up his dog, that was trained to hunt rails, to prevent his catching the young birds that he could find in any suitable breeding place.

2I4. Porzana carolina (Linn.). SORA. A common summer resident, often becoming abundant during early autumn.

2i 5. Porzana noveboracensis (Gme1.). YELLOW RAIL. Rare visitor. I captured one in Longmeadow, October I6, I 894 ; it has also been taken at Northampton (see Birds of Amherst, page 47).

216. Porzana jamaicensis (Gme1.). BLAcK RAIL. A number of years ago, Mr. J. H. Batty, who formerly lived in Springfield, found this bird breeding in Hazardville, Enfield; this is the only record of its appearance here (see Merriam's Birds of Connecticut, page i I9).

219. Gallinula Galeata (Licht.). FiLorIdA GALIINULE. Rare summer resident; I have taken half a dozen 
specimens here during the past twenty years. 'Although I have no positive evidence, still I have little doubt that it occasionally breeds here.

22 I. Fulica americana Gmel. American Coot. A common autumn visitor, but rare in the spring.

222. Crymophilus fulicarius (Linn.). RED PHALAROPE. Accidental visitor; on the 3 oth of September, I 893 , William $\mathrm{H}$. Lee captured two out of a flock of a dozen near Chicopee; these are the specimens in the Museum of Natural History.

223. Phalaropus lobatus (Linn.). NORTHERN Phalarope. Accidental visitor; one was taken in Ware, October I3, I875. (See Bulletin Nutthall Ornithological Club; Vol. 5, page I 22.)

228. Philohela minor (Gme1.). AMERICAN' WoODcock. Regular spring and autumn visitor, and a tolerably common summer resident. Fifteen years ago, woodcock bred regularly and abundantly, but about i 887 they almost ceased to do so, and only occasionally could a brood be found here; this condition continued for about a decade, but during the last three years they have again been more numerous as summer residents.

230. Gallinago delicata (Ord.). Wilson's SNIPE. Common spring and autumn visitor, and I have known of its being here both in midsummer and midwinter.

23I. Macrorhamphus griseus (Gme1.). DOWITCHER. Rare spring and autumn migrant, not as common as formerly.

234. Tringa canutus Linn. KNOT. Accidental visitor; a number of years ago I captured one the last: of .August, which is the only instance known to me of its presence here. 
.235. Tringa maritima Brunn. Purple Sandpiper. Accidental-visitor. I shot one in November, I883, but know of no other record.

239. Tringa maculata Vieill. PeCtoral SANDPIPEŔ. Tolerably common autumn visitor. It formerly made us quite long visits at this season, but now this and all shore birds are killed or driven away very soon after their arrival; at least it is so with those that have selected the vicinity of the river for their feeding ground.

240. Tringa fuscicollis Vieill. WHITE-RUMPED SANDPIPER. Common autumn migrant; occasionally large flocks stop here.

242. Tringa minutilla Vieill. LEAST SANDPIPER. Common spring and autumn visitor.

243. (a) Tringa alpina pacifica (Coues). REDBACKED SANDPIPER. Tolerably common autumn visitor, and I have found it here on one occasion in the spring, but it is rare at that season.. .

: 248. Calidris arenaria (Linn.). SANDERLING. Rare autumn visitor; it probably occurs here in the spring, but I know of no instance of its being seen then.

\section{Totanus melanoleucus (Gme1.). GREATER} YELLOW-LEGS. A common spring and autumn visitor; several years I have foind it aburidant here in May. When decoying for ducks, I have heard far up in the distance, the faint whistle of this bird, and by a rude imitation of its note, have called it down until it would circle close around the wooden imitation of ducks.

255. Totanus flavipes (Gme1.). YELIOW-LEGS. A rare spring and autumn visitor.

256. Helodromas solitarius (Wi1s.). SOL ITARY SANDPIPER. A common early autumn and late spring visitor. 
258. Symphemia semipalmata (Gmel.). WILLET. Rare spring and autumn visitor; I captured one September 8, I 900.

26I. Bartramia longicauda (Bechst.). BARTrAMIAN SANDPIPER. Rather rare summer resident, breeding in Russell, Blandford and some of the other mountain towns. Formerly, it was abundant in the river towns during August, but now only a few individuals visit us.

262. Tryngites subruficollis (Vieill.). BUFF-BREASTED SANDPIPER. Given by Dr. J. A. Allen as a rare spring and autumn visitor, and recorded in Merriam's Birds of Connecticut, as having been taken near Hartford. There is one example in the Science building in Springfield that was captured at Northampton by E. O. Damon.

263. Actitis macularia (I,inn.). Spotted SANDPIPER. Abundant summer resident.

265. Numenius hudsonicus Lath. HUDSONICUS CurLEw. A rare migrant; it has been killed in the vicinity of Hartford (see Merriam's Birds of Connecticut, page I09). I have seen a Curlew in Longmeadow, probably one of this specie; the specimen in the Science building in Springfield, was taken by E. O. Damon at Northampton.

270. Squatarola squatarola (Linn.). B L A C K BELIIED PLOVER. Accidental visitor; some years ago, about the first of June, I found one on the bank of the Connecticut river so tame that it permitted me to row within fifteen feet of it and watch it feed.

272. Charadrius dominicus Mü11. American Golden PLOVER. Rare autumn visitor.

273. Aegialitis vocifera (Linn.). KILIDEER. A rare summer resident; formally, common locally when a great 
many bred in the lower part of Agawam and in Suffield. In August, I898, an unusually large number appeared here.

274. Aegialitis semipalmata Bonap. Semipalmated Plover. Recorded by Dr. J. A. Allen as a not rare autumn visitor. I have taken but one specimen, and I think it now occurs here only as a accidental vi: itor.

277. Aegialitis meloda (Ord.). Prping Plover. Accidental visitor. One record only. (See Birds of Amherst, page 47.)

283 Arenaria interpres (L,inn.). 'TURns'ronf.' Rare autumn visitor.

289. Colinus virginianus (Linn.). В ов-Wн I T E. Common resident, but sometimes, during winters when the ground is covered by deep snow for a long period, it is nearly exterminated. On the I $7^{\text {th }}$ of September, I 898 , I found a brood just hatched.

300. Bonasa umbellus (Linn.). RuFFed Grouse. A common residerit; well protected by law, and a growing sentiment in favor of its enforcement. This bird has other enemies besides man; a species of wood tick often destroys whole broods, some winters the goshawk comes down from the north and persistently follows this grouse, which is its favorite food, and the house cat is responsible for the destruction of great numbers of the very young.

315. Ectopistes migratorius (Linn.). PASSENGER PIGEON. In 1876 , hundreds of thousands of pigeons appeared here, apparently as numerous as in previous years. From then until I 879 or I 880 , a few small flocks only were observed each season. In the spring of 1884 , I saw in Southwick the last pigeon that I have known to have visited this vicinity. 
316. Zenaidura macroura (Linn.). MOURNING Dove. A common summer, and a very rare winter, resident.

325. Cathartes aura (Linn.). Turkex Vulture. Accidental visitor. Dr. Wood notes the presence of one in East Windsor, which is the only record. (See Merriam's Birds of Connecticut, page 92.)

33I. Circus hudsonius (Linn.). Marsh Hawk. A common spring and autumn visitor, and a rare summer resident.

332. Accipiter velox (Wils.). SHARP-SHINNED HAWK. A common spring and autumn visitor, occasionally breeds here, and is often seen in winter. This is the boldest of our birds of prey. Some years ago while decoying ducks, I saw one of these little hawks like a flash fasten itself to the back of a wood duck that was fluttering over the decoys; what would have been the result of this encounter I cannot say, as both were shot while in this position. Once, while watching a flock of juncos in a large oak tree, I saw one of these hawks suddenly make a dart for them, and, selecting its victim, chase the bird back and forth and round about the branches of the tree until the poor junco fell to the ground in a collapse from fright, as it had not been touched by the hawk.

333. Accipiter cooperii (Bonap.). CoOPER's Hawk. Tolerably common summer resident, but much more numerous during migration; rare in winter. This is the hawk that is so destructive to poultry in Western Massachusetts, and for its sins many other useful kinds are made to suffer.

334. Accipiter atricapillus (Wils.). A MERICAN Goshawk. Irregular winter visitor from the north, not generally common. As the flesh of the ruffed grouse is its favorite food, a large visitation of this hawk is not desirable. 
337. Buteo borealis (Gme1.). RED-TAILED HAwr. An abundant migrant both in the spring and in the autumn, sometimes passing through the Connecticut valley in small flocks; also a tolerably common summer and rare winter resident.

339. Buteo lineatus (Gme1.). - RED-SHouldereD HAwk. Very common summer but rare winter resident; I think this hawk breeds here in greater numbers than all other kinds put together.

343. Buteo latissimus (Wils.). BROAD-WINGED HAwk. Breeds regularly and commonly in the mountains west of Westfield; rare in the river towns during the spring and autumn.

\section{7. a Archibuteo lagopus sancti-johannis (Gme1.).} AMERICAN RoUgH-LEGGED HAWk. A conmon winter visitor, but not so numerous as ten years ago. While here it feeds entirely on mice and other rodents; if the ground is covered with snow to a great depth, the difficulty of obtaining food causes it to move further south, but it always returns soon after the snow melts and a substantial portion of the ground is uncovered.

349. Aquila chrysaetos (Linn.). Golden Eagle. There are no late records of the appearance of the Golden Eagle in this vicinity; one was taken in Monson, in November, I 864, and two were captured in Westfield, two years later. (See Allen's Rarer Birds of Massachusetts.)

\section{Haliæetus leucocephalus (Linn.). BALD} EAGLE. Rather uncommon transient visitor in the spring, summer and autumn, and rare in the winter. Dr. J. A. Allen reported it as sometimes breeding. Occasionally it is quite numerous near the river in late summer, feeding on the dead fish that are often to be found in large numbers at that season. On Mt. Tom, once, I saw a Duck Hawk make a sarage attack on a Bald Eagle and drive it from the mountain. 
354. a Falco rusticolus gyrtalco (Linn.). GyrFalcon. Accidental visitor; Mr. E. O. Damon captured one in Northampton, Iiebruary, I 879, which is the specimen in the Science building.

356. Fa1co peregrinus anatum (Bonap.). Duck HAwK. A rare summer resident, breeding on several of the mountain tops in this vicinity, including Mt. 'Tom, where for years its nests have been constantly robbed. Notwithstanding this, and the fact that a hotel has been built on the summit, with electric cars running to it, the Duck Hawk still persists in making this mountain its summer home.

357. Falco columbarius Linn. PIGkON Hawk. Rare spring and autumn visitor. Dr. William Wood was quite sure that it bred in East Windsor, but he had no positive evidence of that fact.

360. Falco sparverius Linn. AmFrican SPARrow HAwk. Common summer resident, not uncommon in winter and more numerous at all seasons than formerly. In I894, a pair built their nest on a platform under the cornice of the six-story building of the Morgan Envelope Company, on Harrison avenue, Springfield, where their young were successfully raised, and nearly every year since I have seen a pair through the breeding season, near the business center of Springfield; one year they adopted the steeple of the First church as their home, where they could be seen every day. Two or three winters ago, a large bag of oats was broken open and the contents scattered in the yard of $1 n y$ unused barn at Tatham, in West Springfield, and to feed on this grain, mice gathered in such great numbers that the barn was overrun with them. In March, a pair of Sparrow Hawks, finding their food supply so abundant, drove out a pair of doves, that were breeding in an apartment of a cote attached to the barn, and there laid their eggs. Though the male was killed, the female persisted, and at the end of thirty-four days the young were hatched and successfully raised. During the time of incubation and the raising of the young, none of the wild birds in the vicinity 
were interfered with by the mother hawk, and even the doves that had been driven out were permitted to nest within a few feet of their former home. The hawks nearly, if not quite, exterminated the mice that at first were so numerous.

\section{Pandion haliaetus carolinensis (Gmel.).} AMERICAN OSPREy. Common during both the spring and autumn migration; often seen here near the Connecticut river, during the summer, but I have no knowledge of its breeding in the vicinity of Springfield. Once while on one of the meadows bordering the river, on a foggy day in April, I saw an Osprey that had been shot fall to the ground slightly wounded, and there uttered the most piteous screams that I ever heard come from a bird. Immediately, there appeared, out of the fog above, a dozen other Ospreys, who for a long time circled around their injured relative with cries of sympathy.

365. Strix pratincola Bonap. American Barn OWL. Accidental visitor from the South; one was taken in Springfield, in May, I868, which is one of the few Massachusetts records. (See Allen's Rarer Birds of Massachusetts.)

366. Asio wilsonianus (Less.). AMERICAN LONGEARED OWL. Tolerably common resident.

367. Asio accipitrinus (Pa11.). ShorT-EARED OWL. A common spring and autumn visitor. During open winters a number stay with us, and I have seen it here in January, when the snow was very deep; it occasionally breeds, but at no season now is it as numerous as fifteen years ago, when it was often found in colonies. Mr. E. O. Damon stated that he once saw a hundred of these birds together on the Northampton ineadows.

368. Syrnium nebulosum (Forst.). BARRFD-OWL. A rather uncommon resident, but occasionally quite numerous in late autumn. Mr. William Street of Easthampton has twice found the nest of this owl. (See Baird, Brewster \& Ridway's North American Birds, Vol. III, page 37.) 
370. Scotiapatex cinerea (Gme1.). Great Gray OWL. Accidental winter visitor. Many years ago one was taken at Westfield; on February 25,1883 , one was taken in Agawam, another in Blandford, March 4, 1896, and Mr. E. O. Damon has taken one at Northampton. These are the only records of its appearance here known to me.

\section{I. Nyctala tengmalmi richardsoni (Bonap.).} RICHARDSON'S OWL. A very rare winter visitor. There are only old records of its appearance in this vicinity; Dr. J. A. Allen obtained one in December, 1859, (see Catalogue of the Birds of Springfield, ) and about the same time one was captured by hand at East Windsor. (See Merriam's Birds of Connecticut, page 73.)

372. Nyctala acadica (Gme1.). SAW-WHET OWL. A rather uncommon winter visitor; probably breeds here occasionally.

373. Megascops asio (Linn.). SCREECH OwL. Abundant resident, often breeding in the residential portion of Springfield.

375. Bubo virginianus (Gme1.). GREAT HORNED OWL. A common resident.

376. Nyctea nyctea (Linn.). SNowy OWL. Rare winter 'visitor; occasionally a number will be seen here, but most seasons it is entirely absent. Dr. William Wood of Somers, Ct., told me that very early one morning, a number of years ago, he saw one fly over Main street, Springfield, near the old railroad station.

377 a Surnia ulula caparoch (Mü11.). AMERICAN Hawk OwL. Very rare winter resident; Mr. E. O. Damon has taken one at Northampton, and two were captured at Hadley in March, I884. (See Birds of Amherst, page 48.) 
387. Coccyzus americanus (Linn.). YELLOWBILLED CUCKoo. Irregular summer resident; some years it is rather common, and in others there are few, if any, here.

388. Coccyzus erythrophthalmus (Wils.). BLACKBILLED CUCKOo. Common and regular summer resident.

390. Ceryle alcyon (Linn.). BELTED KingFisher. Common summer and rare winter resident.

393. Dryobates villosus (Linn.). HAIRY WoODPECKER. A rather uncommon summer and winter resident; in late autumn I have occasionally found them quite numerous.

394 c Dryobates pubescens medianus (Swains.). DOWNY WOODPECKER. A common winter and summer resident.

400. Picoides arcticus (Swains.). ArCtic ThreETOED WOODPECKER. A rare winter resident. It has been taken at East Windsor and Simsbury, Ct., (see Merriam's Birds of Connecticut, page 64,) a pair at Westfield, (see Allen's Rarer Birds of Massachusetts, ) and also on Mt. Nonotuck by Mr. William Street.

402. Sphyrapicus varius (Linn.). YELLOW-BELLIED SAPSUCKER. Tolerably common during its migration, both in the spring and in the autumn ; in April, I 898, it was unusually numerous. Dr. J. A. Allen reported it as an accidental summer visitor.

405 a Ceophloeus pileatus abieticola Bangs. Northern Pileated WoOdPecker. A rare resident, found in the well-wooded portion of the extreme western part of Hampden county. Dr. J. A. Allen, in his "Rarer Birds of Massachusetts," says that Mr. J. G. Scott informed him that he had taken three specimens near. Westfield, and that Dr. Wood writes that one was killed at East Windsor about $I 859$. 
406. Malanerpes erythrocephalus (Linn.). REDHEADED WOODPFCKER. Sixty years ago this bird was common here, it is now an irregular and rather rare visitor, more often seen in early autumn; I have known of an instance of one wintering here. In the summer of 1889 , a pair bred in the western part of Agawam, and in September, 1894, a flock of about fifty made a visit to Forest Park, Springfield, where they remained for several days.

409. Melanerpes carolinus (Linn.). RED-BELIIED WOODPECKer. Accidental visitor. Dr. J. A. Allen observed one here, and one had been taken in Suffield. (See Merriam's Birds of Connecticut, page 65.)

4I 2. a Colaptes auratus 1utens Bangs. NORTHERN I'LICKER. Abundant summer resident, a few remaining during the winter.

417. Antrostomus vociferus (Wi1s.). Whip-poorWILL. A common summer resident.

420. Chordeiles virginianus (Gme1.). N I G F T HAWK. Very common summer resident; during recent years often breeding on the roofs of blocks in the business center of Springfield.

423 Chaetura pelagica (Linn.). Chimney Swifi. Abundant summer resident.

428. Trochilus colubris Linn. Ruby-Throated HumMING BIRD. Common summer resident.

444. Tyrannus tyrannus ( ,inn.). KingBird. Abundant summer resident.

452. Myiarchus crinitus (Linn.). CRESTED FLYCATCHER. Not generally common, but locally a regular summer resident. 
456. Sayornis Phobe (Lath.). PhäE. Common summer resident.

459. Contopus borealis (Swains.). OLIVE-SIDED FLYCATCHER. A rather rare summer resident; breeds regularly at Tatham, in West Springfield. For several successive seasons a pair made their home in the Peabody cemetery, Springfield, but they abandoned that place some five or six years ago.

46I. Contopus virens (Linn.). WOOD PeWEE. Common summer resident.

463. Empidonax flaviventris Baird. YELLOWBELLIED FIYCATCHER. Tolerably common spring and autumn visitor. Once a specimen of this kind was brought to me with a broken wing, and evidently in a half-starved condition; I forced a fly down its throat, and in a few minutes it took them in this unusual way without resistance, and in half an hour it would come across the cage in which it was confined, and eagerly snap a fly from my hand. This was the quickest taming of a wild bird that I have ever known.

465. Empidonax virescens (Vieill.). GREENCRESTED FLYCATCHER. Accidental visitor; it has been taken at Suffield. (See Merriam's Birds of Connecticut, page 58.)

466. a Empidonax traillii alnorum Brewst. AIDER Flycatcher. A rare summer resident; found in the extreme western part of Hampden and Hampshire counties.

467. Empidonax minimus Baird. LEAST FLY CATCHER. Common summer resident.

474. Otocoris alpestris (Linn.). HORnED LARK. A rare spring and autumn visitor.

474. $b$ Otocoris alpestris praticola Hensh. PRAIRIE HORNED LARK. There is an old specimen in the Science 
building that must have been captured here twenty years ago. A flock of twenty-five or more spent the winter of $1896-7$ in Longmeadow.

477. Cyanocitta cristata (Linn.). BLUE JAy. Common resident; more numerous in the spring and autumn.

486. a Corvus corax principalis Ridgw. NORTHERN RAVEN. Accidental visitor. Dr. J. A. Allen records the capture of one here in I859, and Mr. E. O. Damon has taken one at Northampton.

488. Corvus americanus Aud. American Crow. Abundant resident.

490. Corvus ossifragus. Wils. FISH CROw. Rare summer visitor. On June 9, I 896, while a inumber of men were at a shooting match in the suburbs of Springfield, a fish crow fiying over the party was shot and captured. This specimen is in the possession of Mr. William Brewster of Cambridge. I think I have seen and heard the fish crow here on one or two occasions, but except in the instance above mentioned, I know of no positive evidence of its occurrence here.

494. Dolichonyx oryzivorus (Linn.). BовогіNк. Abundant summer resident.

495. Molothrus ater (Bodd.). CowBIRD. Rather common summer resident.

498. Agelaius Phoeniceus (Linn.). RED-wINGED BLACKBIRD. Abundant summer resident. In I896-7, a small flock wintered in a clump of willows close to the Connecticut river in Longmeadow; in January one or two were shot and killed, but the rest remained until March.

50I. Sturnella magna (Linn.). MEADOWLAR Common summer and rather rare winter resident. 
506. Icterus spurius (Linn.). ORCHARD ORIOLE. A not uncommon summer resident in the river towns; it was unusually numerous in 1893 .

507. Icterus galbula (Linn.). BAITIMORE ORIOLE. Abundant summer resident. Individuals of this kind are inclined to vary in their song; I know of one whose notes, to the most casual listener, suggested the tune of Yankee Doodle, and the residents in the vicinity of the oriole's nest gave it the name of the "Yankee Doodle bird."

509. Scolecophagus carolinus (Mü11.). RUSTy BLACKBIRD. Common spring and autumn visitor.

5II. $b$ Quiscalus quiscula' aeneus (Ridgw.). BRONZED GRACKLE. Common summer resident; often seen here in August and September in enormous flocks. A small flock passed a large portion of the winter rgoo-or in Longmeadow. Its near relative, the Purple Grackle, may occasionally occur here, but I have no proof of that fact.

5I4. Coccothraustes vespertinus (Coop.). EVENING GROSBEAR. With the exception of the winter of I889-9o, this bird was never known to appear in this vicinity or elsewhere in New England. At that time there was a large incursion from the northwest into the eastern states, and specimens were taken at Agawam, Brimfield and Amherst. (See The Auk, vol. 7, pages 210-289.)

515. Pinicola enucleator canadensis. (Cab.). PINE Grosbeak. Irregular winter visitor; absent some seasons, common others, and rarely abundant. In i 874-5, they were as numerous in the streets of Springfield as the English sparrows are now.

5I7. Carpodacus purpureus. (Gme1.). PURPLE Finch. Tolerably common summer resident, more numerous during migration; occasionally here during winter. 
521. Loxia curvirostra minor (Brehm). AMERICAN Crossbill. Irregular winter visitor; it may occasionally breed here. In I goo, a pair stayed at Tatham, in West Springfield, through the latter part of the month of May.

522. Loxia leucoptera Gme1. White-Winged CrossBILI. Irregtular winter visitor, appearing not as frequently as the preceding species. It was more numerous here in the winter of I 899 -I 900 than I ever knew it to be before.

528. Acanthis linaria (Linn.). REDPOLL. Irregular wirter visitor, being quite common some seasons. I presume the Greater Redpoll occasionally occurs here.

529. Astragalinus tristis (I,inn.). AMERICAN GOLDFINCH. Common permanent resident.

533. Spinus pinus (Wils.). PINE Siskin. Irregular winter visitor, not usually common.

534. Passerina nivalis (Linn.). Snowflake. Common winter visitor, but not as numerous as it was 20 years ago.

536. Calcarius lapponicus (Linn.). IAAPLAND LonGSPUR. One specimen was taken here November 27, I895, which is the only record of its occurrence here.

540. Poocaetes gramineus (Gme1.). VESPER SPARRow. Common summer resident.

542. a Ammodramus sandwichensis savan a (Wils.). Savanna Sparrow. Common spring and autumn visitor, and a rare summer resident. In I 895-6, one individual wintered in Longmeadow, on the banks of the Connecticut river, where large masses of soil and turf had been undermined by the high water and broken off from the main bank, leaving little irregular valleys between, which were well protected from the weather; here this little sparrow could any day be flushed. I believe this is as far north as the Savanna sparrow has ever been known to winter. 
546. Ammodramus savannarum passerinus (Wi1s.). GRASSHOPPER SPARROW. Common summer resident.

547. Ammodramus henslowii (Aud.). HENsLow's SPARROW. Dr. J. A. Allen reports the capture of one in Springfield, and Mr. William Brewster states that it breeds quite numerously near Amherst. (See foot note, page 200, Minot's Land Birds and Game Birds of New England, 2d edition.)

554. Zonotrichia leucophrys (Forst.). WH I TECROWNED SPARROW. Rare spring and autumn visitor.

558. Zonotrichia albicollis (Gme1.). W H TETHROATED SPARROW. Very common spring and autumn visitor; breeds occasionally in Granville, Blandford, and I presume in Chester. The late Mr. R. B. Hildreth was confident that a pair once bred in Ingersoll dell in Springfield. Under date of August I3, I867, he wrote that he had seen and heard a pair there more than forty times during the summer, always near the same spot, and though he did not find the nest, he believed it to be at no great distance.

559. Spizella monticola (Gme1.). TREE Sparrow. Common winter resident, and abundant in spring and autumn.

560. Spizella socialis (Wils.). ChIPPING SParrow. Abundant summer resident.

563. Spizella pusilla (Wils.). FIELD SPÁR ROW . Common summer resident.

567. Junco hyemalis (Iinn.). SIATE-COLORED JUNCO. An abundant migrant, both in the spring and the autumn, and a few winter here; it occasionally breeds on the mountain tops, including Holyoke, Nonotuck, and Tom. A pair were seen near the pavilion on Mt. Tom the 2 ist of June, Igoo.

581. Melospiza fasciata (Gme1.). Song Sparrow. Abundant summer resident, and often winters here; it is more common during the latter season than is generally supposed. 
583. Melospiza lincolni (Aud.). Lincoln's SPARROW. Dr. J. A. Allen took three specimens at Springfield; Mr. Edwin I. Shores took several at Suffield, and did not consider it rare there. (See N. E. Bird Life, Vol. I, page 252.)

584. Melospiza georgiana (Lath.). Swamp SparRow. Rather uncommon summer resident.

585. Passerella iliaca (Merr.). Fox S PAR Row . Common spring and autumn migrant; sometimes abundant.

587. Pipilo erythrophthalmus (Linn.). TowHEE. Common summer resident.

593. Cardinalis cardinalis (Linn.). CARDINAL. Accidental visitor. (For records of its appearance at Springfield, Belchertown, and Southampton, see G. A. Allen's Rarer Birds of Massachusetts.)

595. Zamelodia 1udoriciana (Linn.). RosEBREASTED GROSBEAK. Common summer resident, occurring in increasing numbers during the past ten years.

598. Cyanospiza cyanea (Linn.). Indigo Bunting. Common summer resident.

604. Spiza americana (Gme1.). Dickcissel. Accidental visitor. Sixty years ago it was considered a common bird in Massachusetts; it was captured in Holyoke in May, I 866, by Mr. C. W. Bennett. (See J. A. Allen's Rarer Birds of Massachusetts.)

608. Piranga erythromelas Vieill. SCARLE'T TANAGER. Common summer resident.

6i I. Progne subis (Iinn.). PUrple Martin. Rare summer resident; at one time it was a common bird here, but now only a few colonies are to be seen. 
6I2. Petrochelidon 1unifrons (Say). CLIFF SWALLow. Rather common summer resident, but not as numerous as formerly. In a diary of the late R. B. Hildreth, it is stated that a colony of these birds took up their residence under the eaves of a barn at the homestead of Festus Stebbins on North Main street in Springfield, about I835, when the land west of this place was an open space running back perhaps a thousand feet to the river, and down until about i 870 they persisted in occupying it as their home, notwithstanding Springfield changed from a town to a city, and in this open space were built a portion of a railroad and numerous buildings,

6r3. Chelidon erythrogastra (Bodd.). BARN SWALLow. Abundant summer resident.

6I4. Tachycineta bicolor (Viei11.). TREE SWALLow. Only a few breed here, but the latter part of the summer they become very numerous, especially along the river, where I have seen towards evening immense flocks alight on the wild rice, which grows profusely along the bank.

6I6. Clivicola riparia (Linn.). BANK SWALLow. Common summer resident.

6I7. Stelgidopteryx serripennis (Aud.). RouǴrHWINGED SWALLOW. There are only three records of its appearance in this vicinty. At Suffield, June 6, I874 (see Nuttall Ornith. Bulletin, Vol. 2, page 2II); at Easthampton May, I85I (see Birds of Amherst, page 49), and at East Hartford (see J. A. Allen's Revised List of Birds of Massachusetts).

6I8. Ampelis garrulus Iinn. BOHEMran Waxwing. It has been taken by the late Dr. William Wood of East Windsor (see Merriam's Birds of Connecticut, page 579). This' is the only instance known to me.

6ig. Ampelis cedrorum (Vieil1.). Cempar Waxwing. Generally a common summer resident, often seen in the last 
part of winter in flocks, but irregular in its appearance at all times. It was more numerous here in September, I 900, than at any time for years.

621. Ianius borealis Vieill. NORTHERN SHRIKE. Common winter visitor.

622. a Lanius 1udovicianus excubitorides (Swains.) WhitE-RUMPED SHRIKE. Has been taken in Amherst. (See Birds of Amherst, page 49.)

624. Vireo olivaceus (Linn.). RED-EYED VIR EO. Abundant summer resident.

627. Vireo gilvus (Vieill.). WARBLING VIREO. Common summer resident.

628. Vireo flavifrons Vieill. YELLOW-THROATED VIREO. Common summer resident; much more numerous than ten years ago; it has a decided preference for the shade trees along the streets of the cities and towns, and in the residential portions of Springfield it is as common as any of the vireo.

629. Vireo solitarius (Wils.). BLUE-HEADED VIREO. Common spring and autumn visitor, and now a rare summer resident. For the four years previous to I 895 this bird was breeding here in increasing numbers; one season three pair nested in the immediate vicinity of the Peabody cemetery in Springfield; since that year I have seen but one pair here in summer. This condition is undoubtedly accounted for by the exceptional cold at the South in the winter of I894-5, which destroyed so many birds.

631. Vireo noveboracensis (Gme1.). WHITE-FYED Vireo. Very rare at Springfield and up the river, although almost abundant in the lower Connecticut valley, and even to the Massachusetts line it is hardly uncommon. Dr. William Wood found several nests at East Windsor, and E. I. Shores of 
Suffield considered it common there, but for some unknown reason it will not cross the line from Connecticut into Massachusetts except as a very rare visitor. Dr. J. A. Allen knew of but one instance of its occurrence near Springfield, and in this state. (See Rarer Birds of Massachusetts.) I found one in Hampden, which is the only time I have seen one in the valley above the Connecticut line.

\section{Mniotilta varia (Linn.). BLACK AND WHITE} WARBLER. Common summer resident.

637. Protonotaria citrea (Bodd.). Prothonotary WARBLER. A rare visitor from the South; three were taken at Northampton in May, I883; one of these is in the collection at the Science building in Springfield.

639. Helmitherus vermivorus (Gme1.). W O RM EATING WARBLER. A rare visitor from the South. E. I. Shores took one in Suffeld, August 22, 1874, and one was seen in Easthampton. (See Part I New England Bird Life, page III.)

64r. Helminthophila pinus (Linn.). BLUE-WINGED WARBLER. I do not know of any instance of its occurrence in this vicinity, but there is one record of the capture at Suffield of the Brewster warbler, which by many is considered to be one of this kind, in different color phase. (See Bul. Nuttall Ornith. Club, Vol. I I I, page I99.)

642. Helminthophila chrysoptera (Linn.). GoLDENWINGED WARBLER. Very rare summer resident. It has been observed in summer by Mr. Allen in Springfield, and by Mr. Bennett in Holyoke (see Baird, Brewer and Ridgway's North American Birds); and W. A. Stearns has seen specimens taken in Amherst (see Birds of Amherst); E. I. Shores has taken several at Suffield (see Merriam's Birds of Connecticut). J. H. Sage says this bird is a common summer resident at Portland, 40 miles down the Connecticut valley from Springfield; he also 
states that the Brewster blue-winged warbler is a regular summer resident there. (See The Auk, I 893, page 208.)

645. Helminthophila rubricapilla (Wils.). NASHVILLE WARBLER. Very common spring and autumn migrant, and rather uncommon summer resident.

646. Helminthophila celata (Say.). ORANGECROWNED WARBLER. Accidental visitor; the only record of its appearance here, and one of the very few in Massachusetts, is by Dr. J. A. Allen, who shot one from quite a number that he found in an orchard on May $15, \mp 863$.

647. Helminthophila peregrina (Wils.). TENNESSEE WARBLER. Rare spring and autumn migrant. Dr. Allen, in the Rarer Birds of Massachusetts, states that he had taken it repeatedly at Springfiekd; at Suffield it was captured as late as June 8 (see Birds of Connecticut, page I4); there is no other evidence of its breeding than finding it here at so late a date. This bird so closely resembles the Nashville warbler that it is well to have it in hand to positively identify it.

\section{8. a Compsothlypis americana usneæ Brewster.} Northere PARULA WARBLER. A common spring and autumn migrant, and rather rare summer resident; breeding only near where Usnea "moss" is found, of which material its nest is always constructed.

650. Dendroica tigrina (Gme1.). C A P E M A Y WARBLER. Rare spring and autumn migrant.

652. Dendroica aestiva (Gmel.). YeLLOW WARBLER. Common summer resident.

654. Dendroica caerulescens (Gme1.). B L A CK THROATED BLUE WARBLER. A common spring and autumn migrant; it is an abundant summer resident on the slope of the mountains just west of Westfield, in the towns of Russell and 
Granville, in heavy woods composed mostly of deciduous trees, chestnut predominating, with an occasional tulip, rock maple, birch and oak, and a few white pine and hemlocks, always with a thick undergrowth of mountain laurel; here I have regularly found it for the last six summers the most abundant warbler in that region, excepting perhaps the oven bird.

655. Dendroica coronata (Linn.). MYRTLE WARBLER. An abundant spring and autumn migrant. A person in whose accuracy in such matters I have great faith, informed me that in the pine woods near the main entrance to Forest park in Springfield, in the summer of 1900 , for nearly half an hour he watched a pair feeding their newly-fledged young. Except on high elevations this is considerably south of their usual breeding range.

657. Dendroica maculosa (Gme1.). M A G N OL I A WARBLER. A common spring and autumn migrant, and I presume it occasionally breeds in the west part of Blandford and Chester.

658. Dendroica rara (Wils.). CeRULEAN WARBLER. $A$ very rare visitor from the West; taken at Suffield June I2, I 875 (Bull. Nutt. Club 2, page 2I). W. A. Stearns reported the capture of three in Amherst, May I9, I884; all females, he says, "they were taken in a thicket back of the college buildings and near a grove of mixed shrubbery."

659. Dendroica pensylvanica (Linn.). ChestnutSIDED WARBLER. Abundant summer resident.

660. Dendroica castanea (Wils.). BAX-BREASTED WARBLER. Usually rather rare spring and autumn migrant; occasionally common; in May, I900, for a few days it was actually abundant. They then came into the very center of the city of Springfield in great numbers; nearly every tree in and around Court square contained one or more, and at Tatham, in West Spring field, after an unusually cold night, I found them feeding on the ground in my garden in a small flock. 
According to Dr. J. A. Allen, in the Catalogue of the Birds of Springfield, one was taken in Springfield July 2, I862, by B. Hosford.

66r. Dendroica striata (Forst.). BLACK-POLL WARBLER. Common spring and autumn migrant.

662. Dendroica blackburniae (Gme1.). B I A ck BURNIAN WARBLER. Rather common spring and autumn migrant; in May, 'I900, it was abundant. In J. A. Allen's Rarer Birds of Massachusetts there is a record of its breeding in Holyoke. I have seen it in Chester in summer, and I presume it breeds there, as it does a short distance west.

663. Dendroica dominica (L,inn.). YELLOW-THROATED WARBLER. A very rare visitor from the South. Dr. David Crary states that during fifteen years of collecting he secured several specimens near Hartford (see Merriam's Birds of Connecticut, page I7). In May, I892, the late William W. Colburn observed one in Springfield about where Ridgewood terrace has since been located.

667. Dendroica virens (Gme1.). Black-THRoATED GreEN WARbLER. Abundant migrant, and not a very common summer resident.

67I. Dendroica vigorsii (Aud.). Pine WARbLER. Common summer resident.

672. Dendroica palmarum (Gme1.). PALM WARBLER. A rare autumn visitor.

672. a Dendroica palmarum hypochrysea Ridgw. YELLOW PALM WARBLER. Common spring and autumn migrant.

673. Dendroica discolot (Vieil1.). PRAIRIE WARBLER. Rather uncommon migrant and rare summer resident. Dr. J. A. Allen stated that it was common here in May one year. 
E. I. Shaw did not consider it rare at Suffield (see Merriam's Birds of Connecticut).

674. Seiurus aurocapillus (Linn.). OVEN BIRD. Abundant summer resident.

675. Seiurus noveboracensis (Gme1.). W A TER Thrush. Common migrant in spring and autumn. Dr. J. A. Allen said that apparently a few breed here, as he had seen them in each of the summer months.

676. Seiurus motacilla (Vieill.). LoUISIANA WATER Thrusf. A rare visitor from the South. On the 28 th of July, I895, one was found dead on the piazza of a house on Crescent hill in Springfield; two instances are mentioned in the "Birds of Amherst" and in the "Rarer Birds of Massachusetts'. Dr. J. A. Allen states that he captured one on Mount Tom.

677. Geothlypis formosa (Wi1s.). KENTUCKY WARBLER. One was taken at suffield, August I6, I876. (See Merriam's Birds of Connecticut, page 22.) This is the only instance known to me of its appearance in this vicinity.

678. Geothlypis agilis (Wils.). CONNECTICUT WARBLER. A rare spring and common autumn migrant; during the latter season sometimes quite numerous.

679. Geothlypis philadelphia (Wils.). MournING WARBLER. Rare spring and autumn migrant.

68I. Geoth1ypis trichas (Linn.). MARYLAND YELLow ThroaT. Abundant summer resident.

683. Icteria virens (Linn.). YELLOW-BREASTED CHAT. Rare but regular summer resident; it is more often observed here now than formerly. 
684. Wilsonia mitrata (Gme1.). HOODED WARBLER. Accidental visitor; it has been taken by E. I. Shores at Suffield. At the lower end of the Connecticut valley it is a common summer resident.

685. Wilsonia pusilla (Wils.). WILSON'S WARBLER. Rare spring and autumn migrant.

686. Wilsonia canadensis (Linn.). C A N A D A N WARBLER. A common spring and autumn migrant; a few may breed in Blandford and Chester, but I have seen none in summer east of Becket.

687. Setophaga ruticilla (Linn.). AMERICAN REDSTAR'T. Common summer resident.

697. Anthus pensilvanicus (Lath.). AMERICAN PIPIT. Common autumn and rather rare spring visitor.

703. Mimus polyglottos (Linn.). Mockingbird. Rare summer. resident. Dr. J. A. Allen in the catalogue of the Birds found at Springfield, states that it had been known to breed in Springfield several times within five years, and that in I 860 two pair nested here. In recent years a pair spent three successive summers in Tatham and bred there. I have repeatedly known of the presence of individuals in this vicinity.

704. Galeoscoptes carolinensis (Linn.). CATBIRD. Common summer resident.

705. Harporhynchus rufus (Linn.). B R ow N THRAsher. Common summer resident.

7I8. Thryothorus ludovicianus (Lath.). Carolina WREN. Accidental visitor; taken at East Hartford (see Auk. Vol. 3, page 489).

72I. Troglodytes aedon Vieill. HOUSE WREN. 
Rather uncommon summer resident; not as numerous as formerly.

722. Anorthura hiemalis (Vieill.). WINTER WREN. Uncommon spring and autumn visitor, and rare winter resident.

724. Cistothorus stellaris (Licht.). SHORT-BILLED MARSH WREN. Rather rare summer resident; not uncommon in autumn; in the latter season it frequents the wild rice along the banks of the Connecticut river.

\section{Cistothorus palustris (Wils.). LONG-BIILED} MARSH WREN. Rather rare summer resident.

726. Certhia familiaris fusca Barton. B R ow N CREEPER. Common spring and autumn migrant and winter resident. Dr. J. A. Allen records a nest being found in Court square, Springfield; that is the only known instance of its breeding here.

727. Sitta carolinensis Lath. WHITE-B REASTED NUTHATCH. Common resident; more numerous during migration.

728. Sitta canadensis Linn. RED-BREASTED NUTHATCH. Rather common in migration, and an irregular winter visitor; some years being entirely absent, and others common. In the winter of 1899 and Igoo, they were more numerous than they had been for a great many years.

73I. Parus bicolor Linn. TUfTed Titmouse. Accidental visitor. It has been taken at Hartford. (See Merriam's Birds of Connecticut, page 9.)

735. Parus atricapillus I,inn. ChICkAdEE. Common resident.

748. Regulus satrapa Licht. GOLDEN-C R OWN D KINGLET. Common spring and autumn visitor, and rare winter resident. 
749. Regulus calendula (Linn.). RUBY-CROWNED KINGLET. Common spring and autumn migrant.

751. Polioptila caerulea (Linn.). B LUE - G R A Y GNATCATCHER. Accidental visitor; one was taken at Elast Hartford, September 21, I 885 (see Auk. Vol. 3, page 487).

755. Hylocichla mustelinus Gmel. Wood Thrush. Common summer resident.

756. Hylocichla fuscescens Steph. WIIson's Thrush. Common summer resident.

757. Hylocichla aliciae (Baird). Gray-CHEEKED THRUSH. Rare late spring and early autumn migrant. I presume the Bicknell's Thrush occasionally occurs here during its migration, but I have no proof of that fact.

758. a Hylocichla ustulatus swainsonii (Cab.). OrIVE-BACKED Thrush. Common migrant; no doubt that it occasionally, but rarely, breeds in some of the mountain towns in the extreme western portion of Hampshire county, as it does just beyond in Berkshire..

\section{9. b Hylocich1a aonalaschkae pallasii (Cab.).} Hermit Thrush. Common migrant and rare summer resident in Chester, Middlefield and Worthington, but at no season as numerous as it was previous to I895, when so many were destroyed by the severe cold at the South.

76I. Merula migratoria (Linn.). AMERICAN Robin. Abundant summer resident, occasionally winters.

766. Sialia sialis (Linn.). BLUEBIRD. Abundant summer resident; I have seen it here every month in the year but January. Rev. William B. O. Peabody, in the report of the Ornithology of Massachusetts, which he wrote at his home in Springfield, spoke of the appearance of the bluebird in January, 1838 ; whether he meant here or elsewhere in Massachusetts, I cannot say. 
Species not included in the list for reason of insufficient evidence, but of likely occurrence here.

47. Larus marinus Linn. GREAT BLACK-BACKED GULI. I think I have seen representatives of this species on the Connecticut river here, but know of none being captured.

58. Larus atricilla . Linn. LAUGHING GULL. A number of years ago I shot a gull which I supposed was one of this kind, but the skin was not preserved, and now having some doubts as to its being a correct identification, I leave it off the list.

77. Hydrochelidon nigra surinamensis (Gme1.). Black TERn. After a severe gale the 28th of August, I 893, a large flock of terns, answering the description of this kind, appeared near the Connecticut river in Longmeadow. About the same time. black terns were observed in two places in Connecticut. (See The Auk. Vol. I I, page 74.)

I6o. Somateria dresseri Sharpe. AMERICAN EIDER. A few years ago I observed on the Connecticut river in Longmeadow, in company with a flock of anas obscura, a duck nearly white, and to all appearances an eider; it was about one hundred yards from me, and I watched it through field glasses for a long time. It finally separated from the black ducks and then disappeared.

Among the other species that are probably occasionally represented here may be mentioned kittiwake, canvas-back, Ipswich sparrow, Nelson sparrow. and Philadelphia vireo.

\section{Introduced Species.}

Coturnix coturnix. EURopean QUAIL. A little more than twenty years ago, for two or three successive years many of these birds were liberated in the vicinity of Springfield. I hardly think any bred here, although statements to the contrary appeared in the newspapers of that day; some were kept 
in captivity from summer until early the following spring, when they were let go; many stayed near here for some months after they were released, but none remained during the following winter after being let loose.

305. Tympanuchus americanus (Reich). PRAIRIE HEN. January 28, I 893 , nearly ninety of this kind were let go in different places about Springfield, all of which soon disappeared.

\section{8. $b$ Pediocæetes phasianellus campestris Ridgw.} Prairie Sharp-taileed Grouse. January I4, I892, about twenty of these birds were liberated. near Springfield, and early the following spring two or three more; one at least survived the summer and was shot the next autumn at East Windsor, some twenty miles from the place where they were released. It was apparent from the first that the experiment of naturalizing them here would prove a failure, as they were altogether too tame for so thickly settled country as this, alighting on barns and approaching farmhouses in the most reckless manner.

493. Sturnus vulgaris Linn. STARIING. In the spring of 1897 , about one hundred were liberated in Forest park in Springfield. Three of these were alive and well early the following spring, but since then I have not seen or heard of any of them.

Passer domesticus. Engrish Sparrow. I cannot name the exact year the mistake was made of introducing English sparrows here, but think it was either 1866 or ' 67 . In 1868 boxes were provided for them in Court square, Springfield. These birds are responsible in a measure for the great increase of injurious insects in the cities and large towns, as wherever the English sparrows are abundant there the native birds, the natural enemies of these insects, are rare, and in the remote and smaller towns, where English sparrows are not numerous, there the native birds are plentiful, and in the latter place any observer will find less evidence of the bad work 
of insects than in the former, notwithstanding the thousands of gallons of poison washes that are poured over vegetation in and around the large centers.

A number of pheasants of different varieties have been turned out in this vicinity during the last three years, and a few valley quail from California. The former could, undoubtedly be made permanent residents here if protected in fact as well as in name.

\section{Extirpated Species.}

306. Tympanuchus cupido (Linn.). HEATH HEN. This bird probably was not common at the time this valley was first occupied by the English. Except along the streams the country was heavily wooded, mostly with massive white pines and white oaks, while this bird prefers a home among dry tracts of scrub oaks or other small growth. Few of the old people here seem to have heard much of the heath hen, but one man in West Springfield belonging to a family of quite famous hunters in old times, pointed out the spot in that town where his uncle had shot one, which must have been before 1820 , and in this family it was considered a remarkable occurrence, as a bird of this kind was so rare. Nuttall, writing in I832, spoke of their being still met with in Westford, Ct., which is a town about thirty miles southeast of Springfield. Mr. S. T. Hammond says that a great many years ago while in Killingly, $\mathrm{C}$. two old hunters pointed out the place where they said the last heath hen in that state was killed. In I818, when the first statute was passed in this state protecting the so-called game birds, this species was not included, and not until thirteen years later was it made unlawful to kill a heath hen in Massachusetts.

\section{3ro. a Meleagris gallopavo fera (Vieil1.). WILD} Turkey. Probably common at the time the Puritans came to this valley in 1636 , but $I$ fail to find any reference to wild turkeys in any of the records or local histories of the early settlements here; some of the writers of early times elsewhere 
in the state describe them as abundant. A few years ago I.interviewed a number of the old residents of some of the towns in this vicinity to ascertain as nearly as possible the time of the disappearance of the wild turkey, and according to their story there seems to have been in about every place one old turkey that survived all others by reason of its alertness; organized bands of hunters would go oust and try to surround it, and finally after many fruitless attempts the end would come in its capture. Nearly all had been exterminated before 1835 except on $\mathrm{Mt}$. Tom range, where one was taken in 1847 , the skin of which is now preserved in the museum in Yale college. A man who was present at the capture of this bird, says that there were others left on the range when this one was killed. Mr. William Street, who lived on Mt. Nonotuck for many years, wrote me that he well remembers hearing wild turkeys near the south end of Mt. Tom in I848 or ' 49 , and that his brothers saw the last one on Mt. Tom in the winter of $1850-51$, and a short time afterwards it was shot by a man from Holyoke. The late Mr. H. B. Lewis of Westfield, stated that in I 852 a wild turkey was seen on this range, and a party of half a dozen had an unsuccessful hunt for it. Mr. S. T. Hammond said that while living in Holyoke in 1853 he was told that a wild turkey had been shot on Mt. Tom the year before, and his informer believed others were still there.

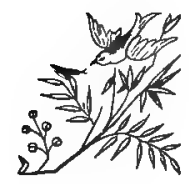




\section{BIBLIOGRAPHY.}

I833. Emmons, EBENEZER. Catalogue of the animals and plants in Massachusetts, published in Amherst. In Hitchcock's Report Geol., Min., Bot. and Zool. of Massachusetts.

i840. Peabody, William B. O. A report on the Ornithology of Massachusetts made to the Legislature. Mr. Peabody was a minister residing in Springfield, and frequently delivered lectures on the subject of Ornithology. The grounds around his house were laid out with a view of attracting birds.

1861. WoOD, WILLIAM. Birds of Connecticut; a series of articles written at East Windsor and published in the Hartford Times.

I 864. ALLEN, J. A. Catalogue of the birds found at Springfield, together with a list of those birds found in the State not observed at Springfield. In Proc. Essex Inst. IV.

1867. AlLEN, J. A. Winter notes of an Ornithologist. In American Nat. I, I 867.

1867. AlLEN, J. A. Ornithological calendar. In American Nat. I, I867.

I 867. Alien, J. A. The birds of spring. In American Nat. I, I 867 .

1876. Keyes, F. H. May songsters at Springfield, Massachusetts. In Forest and Stream VI, June 20, I 876.

I877. MERRIAM, C. HarT. A review of the birds of Connecticut. In Trans. Conn. Acad. Io, also separate vol., New Haven, I877; with many references to birds observed at East Windsor and Suffield. 
I887. ClARK, HERBERT L. The birds of Amherst and vicinity, published in Amherst, I887.

I891. Colburn, Wilitiam W. and R. O. Morris. Birds of the Connecticut river valley in Massachusetts.

I 893. WATERS, Edward S. Birds of Holyoke.

Igoo. Faxon, Walter, and Ralph Hoffman. Birds of Berkshire county. 


\section{ERRATA.}

Page 12, No. 197. First line. Substitute Snowy for Snow.

Page I6, No. 262. Tryngites subruficollis. Under this head, so much as refers to an example in the Science building should be stricken from the list, as this specimen was not correctly identified.

Page I6, No. 265. First line, last word. Substitute Hudsonian for Hudsonicus.

Page 22, No. 370. First line. Substitute Scotiaptex for Scotiapatex.

Page 24, No. 406. First line. Substitute Melanerpes for Malanerpes. Page 30, No. 583. First line. Substitute lincolnii for lincolni. 



\section{INDEX.}

ACANTHIS linaria, 28.

Accipiter atricapillus, I8. cooperii, I8. velox, $\mathrm{x} 8$.

Actitis macularia, I6.

E Eialitis meloda, I7. semipalmata, $1_{7}$. vocifera, 16.

Agelaius phoniceus, 26.

Ail' sponsa, Io.

Alle alle, 7 .

Ainmodramus henslowii, 29. sandwichensis savanna, 28 . savannarum passerinus, 29..

Ampelis cedrorum, $3 \mathrm{I}$. garrulus, 3 I.

Anas boschas, 8 . obscura, 9.

Anorthura hiemalis, 39 .

Anthus pensilvanicus, 38 .

Antrostomus vociferus, 24.

Aquila chrysaètos, I9.

Archibuteo lagopus sancti-johannis, 19.

Ardea candidissima, I2. egretta, I2.

herodias, I 2. virescens, I3.

Ardetta exilis, I2.

Arenaria interpres, I7.

Asio accipitrinus, 2r. wilsonianus, $2 x$.

Astragalinus tristis, 28.

Aythya affinis, Io.

americana, Io. collaris, Io. marila, Io.

BAIDPATE, 9 .

Bartramia longicauda, 16.

Bittern, American, I2.

Least, I2.

Blackbird, Red-winged, 26. Rusty, 27.

Bluebird, 40 .

Bobolink, 26.

Bob-white, I 7 .

Bonasa umbellus, I 7 .

Botaurus lentiginosus, I2.

Brant, I2.
Branta bernicla, I 2. canadensis, 12.

Bubo virginianus, 22.

Buffle-head, Ir.

Bunting, Indigo, 30.

Buteo botealis, r9. latissimus, I. lineatus, Ig.

Calcarius lapponicus, 28.

Calidris arevaria, 15.

Cardinal, 30.

Cardinalis cardinalis, 30.

Carpodacus purpureus, 27.

Catbird,..38.

Cathartes aura, I8.

Ceophlœus pileatus abieticola, 23 .

Certhia familiaris fusca, 39 .

Ceryle alcyon, 23 .

Chætura pelagica, 24 .

Charadrius dominicus, I6.

Charitonetta albeola, II.

Chat, Yellow-breasted, 37.

Chaulelasmus strepera, 9 .

Chelidon erythrogastra, 3r.

Chen hyperborea nivalis, II.

Chickadee, 39 .

Chordeiles virginianus, 24.

Circus hudsonius, I8.

Cistothorus palustris, 39 . stellaris, 39 .

Clangula clangula americana, II.

Clivicola riparia, 3 I.

Coccothraustes vespertinus, 27 .

Coccyzus americanus, 23. erythrophthalmus, 23 .

Colaptes auratus lutens, 24 .

Colinus virginianus, I7.

Colymbus auritus, 6 . holbœellii, 6.

Compsothlypis americana usneæ, 34.

Contopus borealis, 25 . virens, 25.

Coot, American, 14 .

Cormorant, Double-crested, 8.

Corvus americanus, 26. corax principalis, 26. ossifragus, 26.

Coturnix coturnix, 4I. 
Cowbird, 26.

Creeper, Brown, 39.

Crossbill, American, 28.

White-winged, 28.

Crow, American, 26.

Fish, 26.

Crymophilus fulicarius, I4.

Cuckoo, Black-billed, 23. Yellow-billed, 23.

Curlew, Hudsonian, I6.

Cyanocitta cristata, 26 .

Cyanospiza cyanea, 30 .

Dafría acuta, Io.

Dendroica æestiva, 34 .

blackburniæ, 36 .

cærulescens, 34 .

castanea, 35 .

coronata, 35 .

discolor, 36 .

Dendroica dominica, 36 . maculosa, 35. palmarum, 36 . palmarum hy pochrysea, $3^{6}$. pensylvanica, 35 .

rara, 35 .

striata, 36.

tigrina, 34 .

vigorsii, 36 . virens, 36 .

Dickcissel, 30 .

Dolichonyx oryzivorus, 26.

Dove, Mourning, I8.

Dovekie, 7 .

Dowitcher, I4.

Dryobates pubescens medianus, 23. villosus, 23.

Duck, American Scaup, to. Black, 9 .

Lesser Scaup, Io.

Ring-necked, ro.

Ruddy, I I.

Wood, Io.

EAGLE, Bald, I9. Golden, I 9.

Ectopistes migratorius, I7.

Egret, Americau, I2.

Eider, American, 4r.

Empidonax flaviventris, 25.

minimus, 25.

traillii alnorum, 25 .

virescens, 25 .

Erismatura jamaicensis, II.
FALCo columbarius, 20 . peregrinus anatum, 20 . rusticolus gyrfalco, 20. sparverius, 20.

Fiuch, Purple, 27.

Flicker, Northern, 24.

Flycatcher, Alder, 25.

Crested, 24.

Green-crested, 25.

Least, 25.

Olive-sided, 25.

Yellow-bellied, 25 .

Fulica americana, I4.

GADWALI, 9.

Galeoscoptes carolinensis, $3^{8}$.

Gallinago delicata, I4.

Gallinula galeata, I3.

Gallinule, Florida, I3.

Gavia imber, 6. lumme, 6.

Geothlypis agilis, 37 . formosa, 37 . philadelphia, 37 . trichas, 37.

Gnatcatcher, Blue-gray, 40.

Golden-eye, American, I I.

Goldfinch, American, 28.

Goose, Canada, I2. Greater Snow, II.

Goshawk, American, 18.

Grackle, Brouzed, 27.

Grebe, Holbœll's, 6. Horved, 6. Pied-billed, 6.

Grosbeak, Evening, 27. Pine, 27.

Rose-breasted, 30 .

Grouse, Prairie Sharp-tailed, 42. Ruffed, I7.

Gull, Bonaparte's, 7. Great Black-backed, 4I.

Herring, 7 . Laughing, 4I.

Gyrfalcon, 20.

'Har, exe'rus leucocephalus, I9.

Harelda hyemalis, II.

Harporhynchus rufus, 38 .

Hawk, American Rough-legged, Ig.

American Sparrow, 20.

Broad-winged, 19.

Cooper's, I8.

Duck, 20.

Marsh, r8. 
Hawk, Pigeon, 20.

Red-shouldered, I9.

Red-tailed, I9.

Sharp-shinned, 18.

Helminthophila celata, 34 . chrysoptera, 33 .

leucobronchialis, 33 .

peregrina, 34 .

pinus, 33.

rubricapilla, 34 .

Helmitherus vermivorus, 33 .

Helod romas solitarius, I5.

Hen, Heath, 43.

Prairie, 42.

Heron, Black-crowned Night, I3. Great Blue, 12.

Green, I3.

Snowy, I2.

Hummingbird, Ruby-throated, 24 .

Hydrochelidon nigra surinamensis, $4 \mathrm{I}$.

Hylocichla aliciæ, 40. aonalaschkæ pallasii, 40 .

fuscescens, 40 .

mustelinus, 40 .

ustulatus swainsonii, 40 .

ICTERIA virens, 37 .

Icterus galbula, 27 .

spurius, 27.

JAY, B1ue, 26.

Junco hyemalis, 29.

Junco, Slate-colored, 29.

KIILDEER, I6.

Kingbird, 24.

Kingfisher, Belted, 23.

Kinglet, Golden-crowned, 39 .

Knot, I4.

Ruby-crowned, 40 .

LANIUS borealis, 32 . ludovicianus excubitorides, 32.

Lark, Horned, 25.

Prairie Horned, 25.

Larus argentatus, 7 .

atricilla, 4I.

marinus, $4 x$. philadelphia, 7 .

Longspur, Lapland, 28.

Loon, 6 .

Red-throated, 6.

Lophodytes cucullatus, 8 .
Loxia curvirostra minor, 28. leucoptera, 28.

MaCroRhamphus griseus, I4. Mallard, 8.

Mareca americana, 9 .

Martin, Purple, 3 .

Meadowlark, 26.

Megascops asio, 22.

Melanerpes carolinus, 24. erythrocephalus, 24.

Meleagris gallopavo fera, 43 .

Melospiza fasciata, 29. georgiana, 30 . lincolnii, 30 .

Merganser, American, 8. Hooded, 8. Red-breasted, 8.

Merganser americanus, 8 . serrator, 8.

Merula migratoria, 40.

Mimus polyglottos, 38 .

Mniotilta varia, 33 .

Mockingbird, 38 .

Molothrus ater, 26.

Murre, Brïunich's, 6 .

Myiarchus crinitus, 24.

NETTION carolinensis, 9 .

Nighthawk, 24 .

Numenius hudsonicus, I6.

Nuthatch, Red-breasted, 39 . White-breasted, 39 .

Nyctala acadica, 22. tengmalmi richardsoni, 22.

Nyctea nyctea, 22.

Nycticorax nycticorax nævius, I3.

Oceanodroma leucorhoa, 7 .

Oidemia deglandi, I I. perspicillata, II.

Old-squaw, I I.

Oriole, Baltimore, 27. Orchard, 27.

Osprey, American, 2r.

Otocoris alpestris, 25 .

Oven-bird, 37. alpestris praticola, 25 .

Owl, American Barn, $2 \mathrm{I}$.

American Hawk, 22.

American Long-eared, 21.

Barred, 2I.

Great Gray, 22.

Great Horned, 22.

Richardson's, 22. 
Ow1, Saw-whet, 22.

Screech, 22.

Short-eared, 2 I.

Snowy, 22.

PANDION haliaßtus carolinensis, 21.

Parus atricapillus, 39 .

bicolor, 39.

Passer domesticus, 42.

Passerella iliaca, 30.

Passerina nivalis, 28.

Pediocæetes phasianellus campestris, 42.

Petrel, Leach's, 7.

Petrochelidon lunifrons, 3I.

Pewee, Wood, 25.

Phalacrocorax dilophus, 8.

Phalarope, Northern, I 4 . Red, $x 4$.

Phalaropus lobatus, I4.

Philohela minor, I4.

Phobe, 25.

Picoides arcticus, 23.

Pigeon, Passenger, I7.

Pinicola enucleator canadensis, 27.

Pintail, Io.

Pipilo erythrophthalmus, 30.

Pipit, American, 38.

Piranga erythromelas, 30 .

Plover, American Golden, I6. Black-bellied, J6. Piping, I 7 .

Semipalmated, I7.

Podilymbus podiceps, 6 .

Polioptila cærulea, 40.

Poocætes gramineus, 28.

Porzana carolina, I3. jamaicensis, $r_{3}$. noveboracensis, I3

Progne subis, 30.

Protonotaria citrea, 33 .

QUaIL, European, 4I.

Querquedula discors, 9.

Quiscalus quiscula æueus, 27.

RAII, Black, I3.

Clapper, I3.

King, I3.

Virginia, I3.

Yellow, I3.

Rallus crepitans, $\mathrm{r} 3$.

elegans, I3.

virginianus, I3.
Raven, Northern, 26.

Redhead, Io.

Redpoll, 28.

Redstart, American, 38 .

Regulus calendula, 40 . satrapa, 39.

Robin, American, 40.

Rynchops nigra, 7 .

SANDERLING, I5.

Sand piper, Bartramian, I6. Buff-breasted, 16.

Least, I5.

Pectoral, I5.

Purple, 15.

Red-backed, 15 .

- Solitary, 15.

Spotted, I6.

White-rumped, $\mathrm{r}_{5}$.

Sapsucker, Yellow-bellied, 23.

Sayornis phobe, 25 .

Scolecophagus carolinus, 27.

Scoter, Surf, II.

- White-winged, I I.

Scotiaptex cinerea, 22.

Seiurus aurocapillus, 37 . motacilla, 37 .

noveboracensis, 37 .

Setophaga ruticilla, 38 .

Shoveller, Io.

Shrike, Northern, 32.

White-rumped, 32 .

Sialia sialis, 40 .

Siskin, Pine, 28.

Sitta canadensis, 39 . carolinensis, 39 .

Skimmer, Black, 7 .

Snipe, Wilson's, I4.

Snowflake, 28.

Somateria dresseri, 4I.

Sora, $\mathrm{r}_{3}$.

Sparrow, Chipping, 29.

English, 42.

Field, 29.

Fox, 30.

Grasshopper, 29.

Henslow's, 29.

Lincoln's, 30 .

Savanna, 28.

Song, 29.

Swamp, 30 .

Tree, 29.

Vesper, 28.

White-crowned, 29.

White-throated, 29.

Spatula clypeata, ro.

Sphyrapicus varius, 23. 
Spinus pinus, 28.

Spiza americana, 30 .

Spizella monticola, 29. pusilla, 29. socialis, 29.

Squatarola squatarola, I6.

Starling, 42.

Stelgidopteryx serripennis, 3 I.

Sterna hirundo, 7.

Strix pratincola, 2 I.

Sturnella magna, 26.

Sturnus vulgaris, 42.

Surnia ulula caparoch, 22.

Swallow, Bank, 3 I. Barn, 3r.

Cliff, $3 \mathrm{I}$.

Rough-winged, 3 r.

Tree, 3 I.

Șwift, Chimney, 24.

Symphemia semipalmata, I6.

Syrnium nebulosum, $2 I$.

TACHYCINE'TA bicolor, 3 I.

Tauager, Scarlet, 30.

Teal, Blue-winged, 9.

Tern, Black, 4I. Green-winged, 9. Common, 7 .

Thrasher, Brown, 38 .

Thrush, Gray-cheeked, 40. Hermit, 40.

Olive-backed, 40.

Wilson's, 40.

Wood, 40 .

Thryothor us ludovicianus, 38 .

Titmouse, Tufted, 39 .

Totanus flavipes, 15 . melanoleucus, I5.

Towhee, 30 .

Tringa alpina pacifica, I5.

canutus, 14 .

fuscicollis, 15 .

maculata, I5.

maritima, I5.

minutilla, I5.

Trochilus colubris, 24.

Troglodytes aedon, 38 .

Tryngites subruficollis, I6.

Turkey, Wild, 43 .

Turnstone, I7.

Tympanuchus americanus, 42. cupido, 43.

Tyranuus tyrannus, 24 .

URIA lomvia, 6.
VIREO, Blue-headed, 32.

Red-eyed, 32 .

Warbling, 32 .

White-eyed, 32 .

Yellow-throated, 32.

Vireo flavifrons, 32 .

gilvus, 32 .

noveboracensis, 32 .

olivaceus, 32 .

solitarius, 32 .

Vulture, Turkey, r8.

WARBLER, Bay-breasted, 35 .

Black and White, 33 .

Blackburnian, 36 .

Black-pol1, 36 .

Black-throated Blue, 34 .

Black-throated Green, 36 .

Blue-winged, 33 :

Brewster's, 33 .

Canadian, 38 .

Cape May, 34 .

Cerulean, 35 .

Chestnut-sided, 35 .

Connecticut, 37 .

Golden-winged, 33 .

Hooded, 38 .

Kentucky, 37 .

Magnolia, 35 .

Mourning, 37.

Myrtle, 35 .

Nashville, 34 .

Northern Parula, 34.

Orange-crowned, 34 .

Palm, 36.

Pine, 36.

Prairie, 36.

Prothonotary, 33 .

Tennessee, 34 .

Wilson's, 38 .

Worm-eating, 33 .

Yellow, 34.

Yellow Palm, 36.

Yellow-throated, 36 .

Water-Thrush, 37 .

Louisiana, 37 .

Waxwing, Bohemian, 3 I.

Cedar, 3I.

Whip-poor-will, 24.

Willet, r6.

Wilsonia canadensis, $3^{8}$.

mitrata, 38 . pusilla, 38 .

Woodcock, Atnerican, I4.

Wood pecker, Arctic Three-toed, 
Woodpecker, Downy, 23.

Hairy, 23.

Northern Pileated, 23.

Red-bellied, 24.

Red-headed, 24 .

Wren, Carolina, 38.

House, 38 .

Long-billed Marsh, 39.

Short-billed Marsh, 39.
Wren, Winter, 39 .

YELLOW-LEGS, 15 .

Greater, I5.

Yellow-throat, Maryland, 37.

Zamelodia 1udoviciana, 30 .

Zenaidura macroura, I8.

Zonotrichia albicollis, 29.

leucophrys, 29. 





